\title{
Exosome-mediated radiosensitizing effect on neighboring cancer cells via increase in intracellular levels of reactive oxygen species
}

\author{
AI NAKAOKA ${ }^{1}$, MAKIKO NAKAHANA $^{1}$, SACHIKO INUBUSHI $^{1}$, HIROAKI AKASAKA $^{1}$, \\ MOHAMMED SALAH ${ }^{1,2}$, YOSHIKO FUJTA ${ }^{1}$, HIKARU KUBOTA ${ }^{1}$, MENNAALLAH HASSAN ${ }^{1,3}$, \\ RYO NISHIKAWA $^{1}$, NARITOSHI MUKUMOTO ${ }^{1}$, TAKEAKI ISHIHARA ${ }^{1}$, DAISUKE MIYAWAKI ${ }^{1}$, \\ TAKASHI SASAYAMA ${ }^{4}$ and RYOHEI SASAKI ${ }^{1}$ \\ ${ }^{1}$ Division of Radiation Oncology, Kobe University Graduate School of Medicine, Kobe 650-0017, Japan; \\ ${ }^{2}$ Department of Biochemistry, Faculty of Veterinary Medicine, South Valley University, Qena 83523, Egypt; \\ ${ }^{3}$ Department of Clinical Oncology, Faculty of Medicine, Sohag University, Sohag 82524, Egypt; \\ ${ }^{4}$ Department of Neurosurgery, Kobe University Graduate School of Medicine, Kobe 650-0017, Japan
}

Received September 11, 2020; Accepted January 12, 2021

DOI: $10.3892 /$ or.2021.7964

\begin{abstract}
The precise mechanism of intercellular communication between cancer cells following radiation exposure is unclear. Exosomes are membrane-enclosed small vesicles comprising lipid bilayers and are mediators of intercellular communication that transport a variety of intracellular components, including microRNAs (miRNAs or miRs). The present study aimed to identify novel roles of exosomes released from irradiated cells to neighboring cancer cells. In order to confirm the presence of exosomes in the human pancreatic cancer cell line MIAPaCa-2, ultracentrifugation was performed followed by transmission electron microscopy and nanoparticle tracking analysis (NanoSight) using the exosome-specific surface markers CD9 and CD63. Subsequent endocytosis of exosomes was confirmed by fluorescent microscopy. Cell survival following irradiation and the addition of exosomes was evaluated by colony forming assay. Expression levels of miRNAs in exosomes were
\end{abstract}

Correspondence to: Dr Ryohei Sasaki, Division of Radiation Oncology, Kobe University Graduate School of Medicine, 7-5-2 Kusunokicho, Chuouku, Kobe 650-0017, Japan

E-mail: rsasaki@med.kobe-u.ac.jp

Abbreviations: miRNA, microRNA; TEM, transmission electron microscope; ROS, reactive oxygen species; $\mathrm{C}-\mathrm{H}_{2} \mathrm{DCF}$, 2',7'-dichlorodihydrofluorescein diacetate; $\gamma$-H2AX, phosphorylated histone 2AX; SOD1, Cu/Zn superoxide dismutase enzyme; SOD2, Mn-superoxide dismutase enzyme; 3'-UTR, 3'-untranslated region; RIBE, radiation-induced bystander effect; MEM, minimal essential medium; TRITC, tetramethyl rhodamine isothiocyanate; NAC, N-acetyl-L-cysteine; NTA, nanoparticle tracking analysis; RNS, reactive nitrogen species; shRNA, small hairpin RNA; RT-q, reverse transcription-quantitative; si, small interfering

Key words: exosomes, cancer cells, reactive oxygen species, miRNA, DNA damage, radiation, membrane vesicles, extracellular vesicles then quantified by microarray analysis, while protein expression levels of $\mathrm{Cu} / \mathrm{Zn}$ - and Mn-superoxide dismutase (SOD1 and 2, respectively) enzymes in MIAPaCa-2 cells were evaluated by western blotting. Results showed that the uptake of irradiated exosomes was significantly higher than that of non-irradiated exosomes. Notably, irradiated exosomes induced higher intracellular levels of reactive oxygen species (ROS) and a higher frequency of DNA damage in MIAPaCa-2 cells, as determined by fluorescent microscopy and immunocytochemistry, respectively. Moreover, six up- and five downregulated miRNAs were identified in 5 and 8 Gy-irradiated cells using miRNA microarray analyses. Further analysis using miRNA mimics and reverse transcription-quantitative PCR identified miR-6823-5p as a potential candidate to inhibit SOD1, leading to increased intracellular ROS levels and DNA damage. To the best of our knowledge, the present study is the first to demonstrate that irradiated exosomes enhance the radiation effect via increasing intracellular ROS levels in cancer cells. This contributes to improved understanding of the bystander effect of neighboring cancer cells.

\section{Introduction}

Exosomes are membrane vesicles with a diameter of 30-100 nm and constitute a subset of extracellular vesicles. As exosomes carry various bioactive molecules, such as enzymes, cytokines, eicosanoids and small RNAs, they serve a key role in intercellular communication (1). Moreover, exosomes are unique in that they are formed and secreted by the cellular endosomal pathway. They are subsequently sorted based on different membrane-trafficking routes that involve recycling of exosomes back to the plasma membrane and formation of late endosomes and their degradation in lysosomes or integration into exosomes in the multi-vesicular body (2). Exosomes also serve critical roles in cancer progression, intercellular communication, tumor-stromal interactions, activation of signaling pathways and immunomodulation, and may have crucial functions that are currently unknown $(1,3)$. 
Reactive oxygen species (ROS) levels are increased in many types of cancer cell, such as breast and colon cancer cells $(4,5)$ compared with normal cells (6). While a moderate increase in ROS levels can promote cell proliferation and differentiation (7), high ROS levels can cause oxidative damage to lipids, proteins and DNA; therefore, maintaining ROS homeostasis is crucial. Cells maintain ROS homeostasis by balancing ROS generation and elimination via antioxidant molecules, such as superoxide dismutase (SOD) (8). Radiotherapy potently induces massive cell death by triggering apoptosis in cancer cells via the generation of ROS (9), such as superoxide anions and hydroxyl radicals and hydrogen peroxide $\left(\mathrm{H}_{2} \mathrm{O}_{2}\right)$ following the radiolysis of water in the extracellular environment; these highly reactive entities are toxic to both cancer cells and surrounding normal tissue (10). In our previous study (11), MIAPaCa-2 cells were found to be more radio-resistant than other pancreatic cancer cell lines. Moreover, Doskey et al (12) reported that the capabilities or rate constants for ROS reduction differed between 15 tumor and 10 normal cell lines of various tissue types, and that the MIAPaCa-2 cell line had the smallest rate constants and catalase activity for $\mathrm{H}_{2} \mathrm{O}_{2}$ removal.

MicroRNAs (miRNAs or miRs) are small non-coding RNAs composed of 18-22 nucleotides that perform a regulatory role by binding to target mRNAs via multiple imperfect base pairings within 3'-untranslated region (3'-UTR). miRNAs have a wide range of targets that allow them to modulate many pathways involved in cancer progression, including cell proliferation, apoptosis, metastasis and angiogenesis (13). They are differentially expressed in normal and cancer cells; certain miRNAs act as tumor suppressors while others serve as oncogenes, thus promoting tumor initiation and progression (14). Expression levels of miRNAs are altered in both radiation-exposed cancer cells (15-17) and normal cells $(18,19)$ and their expression profiles are modulated in response to DNA damage $(20,21)$. However, whether these altered miRNAs are delivered to recipient cells via exosomes, thus contributing to cell-to-cell communication, remains unclear.

Irradiated cells generate communication signals and subsequently cause biological changes in neighboring or distant non-irradiated cells; this phenomenon is referred to as the radiation-induced bystander effect (RIBE). A variety of signaling molecules, such as ROS $(22)$, cytokines $(23,24)$ and exosomes (25), are initiators of such bystander responses. However, the role of exosomes in RIBE and the association between ROS and exosomes remain unclear.

The present study evaluated the role of exosomes in the radiation response by investigating intracellular ROS and antioxidant levels, DNA damage, and cell survival using the human pancreatic cancer cell line MIAPaCa-2.

\section{Materials and methods}

Cell culture. The MIAPaCa-2 human pancreatic cancer cell line was obtained from Japanese Collection of Research Bioresources Cell Bank (Tokyo, Japan) and maintained in minimal essential medium (MEM) supplemented with $10 \%$ (vol/vol) fetal bovine serum (both Sigma-Aldrich; Merck KGaA), $1 \%$ penicillin-streptomycin mix and 1\% MEM non-essential amino acid solutions (100X; both Nacalai Tesque, Inc.) in a humidified atmosphere containing $5 \% \mathrm{CO}_{2}$ at $37^{\circ} \mathrm{C}$. The doubling time of MIAPaCa-2 cells was 20-23 h (26).

Reagents. The following antibodies were purchased: Anti-cytochrome $c$ and anti-phosphorylated histone $\mathrm{H} 2 \mathrm{AX}(\gamma-\mathrm{H} 2 \mathrm{AX})$ from Cell Signaling Technology, Inc.; anti-CD63 from BD Biosciences; donkey anti-goat IgG, $\mathrm{F}\left(\mathrm{ab}^{\prime}\right)_{2}$-horseradish peroxidase (HRP), HRP-conjugated

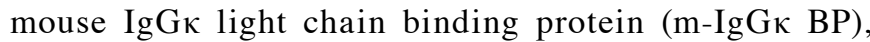
anti-actin and anti-CD9 from Santa Cruz Biotechnology, Inc.; anti-SOD1 and anti-SOD2 from Merck KGaA; and rabbit anti-sheep IgG-HRP and tetramethyl rhodamine isothiocyanate (TRITC)-conjugated anti-rabbit secondary antibody from Dako (Agilent Technologies, Inc.). The following reagents were purchased: $\mathrm{PKH}-67$, a lipophilic dye, and N-acetyl-L-cysteine (NAC) from Sigma-Aldrich; Merck KGaA; Hoechst 33342 and 2',7'-dichlorodihydrofluorescein diacetate $\left(\mathrm{C}-\mathrm{H}_{2} \mathrm{DCF}\right)$ from Thermo Fisher Scientific, Inc.; methylene blue from FUJIFILM Wako Pure Chemical Corporation; and DAPI and wheat germ agglutinin (WGA), Alexa Fluor 594 conjugate from Invitrogen (Thermo Fisher Scientific, Inc.).

Isolation and morphological evaluation of exosomes. Exosomes were isolated from media-conditioned cells by ultracentrifugation, as previously described (27). Briefly, MIAPaCa- 2 cells were seeded at $1.5 \times 10^{6}$ cells per $T 75 \mathrm{~cm}^{2}$ flask and irradiated after substituting the media with exosome-depleted $10 \%$ FBS cell culture media (Sigma-Aldrich; Merck KGaA). The cell culture media was centrifuged at 2,000 $\mathrm{x} \mathrm{g}$ for $10 \mathrm{~min}$ at $4^{\circ} \mathrm{C}$ and the supernatant was filtered through a $0.22-\mu \mathrm{m}$ Minisart ${ }^{\circledR}$ syringe filter (Sartorius AG). The supernatant was centrifuged at $150,000 \mathrm{x}$ g for $90 \mathrm{~min}$ at $4^{\circ} \mathrm{C}$. The pellet was washed with PBS and again centrifuged at $150,000 \mathrm{x} \mathrm{g}$ for $90 \mathrm{~min}$ at $4^{\circ} \mathrm{C}$ and resuspended in $50 \mu \mathrm{l}$ PBS. Then, the total amount of protein in the exosomes was measured using a Qubit ${ }^{\mathrm{TM}}$ Protein Assay kit (Invitrogen; Thermo Fisher Scientific, Inc.).

The exosomes isolated from non-irradiated (0 Gy-Exo) and 5 Gy irradiated cells (5 Gy-Exo) were evaluated by transmission electron microscopy (TEM). Briefly, $4 \mu 1$ PBS suspension of isolated exosomes was loaded onto carbon-coated 200-mesh copper grids for $1 \mathrm{~min}$ at $25^{\circ} \mathrm{C}$. Excessive fluid was removed using filter paper. The adsorbed exosomes were negatively stained with $2 \%$ uranyl acetate for $30 \mathrm{sec}$ at $25^{\circ} \mathrm{C}$. Finally, the air-dried exosome-containing grids were observed under a TEM microscope (JEM-1400 plus; JEOL, Ltd.) at $120 \mathrm{kV}$ (magnification, x50,000). Exosome size, concentration and distribution were analyzed by nanoparticle tracking analysis (NTA) software using NanoSight NS300 (Malvern Panalytical). The software was optimized to identify and track each particle on a frame-by-frame basis and Brownian movement was tracked and measured from frame to frame.

Cellular internalization analysis. Exosomes were labeled with the green fluorescent dye PKH-67 using the PKH67 Green Fluorescent Cell Linker kit for General Cell Membrane Labeling (Sigma-Aldrich; Merck $\mathrm{KGaA}$ ) as previously described (28). Briefly, $6 \mu \mathrm{g} 0$ and 5 Gy-Exo were labeled with $2 \mu \mathrm{M}$ PKH-67 for $5 \mathrm{~min}$ at $25^{\circ} \mathrm{C}$. Then, free PKH-67 
was removed by centrifugation $14,000 \mathrm{x} \mathrm{g}$ for $2 \mathrm{~min}$ at $25^{\circ} \mathrm{C}$ using the VIVACON 500 ultracentrifugation device (100,000 MWCO; Sartorius Stedim Biotech; Sartorius AG). MIAPaCa-2 cells were cultured for $24 \mathrm{~h}$ at $37^{\circ} \mathrm{C}$, after which the culture media was replaced with that containing the labeled exosomes. Following incubation at $37^{\circ} \mathrm{C}$ overnight, cells were gently washed twice with PBS and fixed by $4 \%$ paraformaldehyde solution (Nacalai Tesque) for $20 \mathrm{~min}$ at $25^{\circ} \mathrm{C}$. After washing with Hanks' Balanced Salt Solution (Gibco; Thermo Fisher Scientific, Inc.), cells were incubated with $10 \mu \mathrm{g} / \mathrm{ml}$ WGA, Alexa Fluor 594 conjugate (Invitrogen, Thermo Fisher Scientific, Inc.) for $10 \mathrm{~min}$ at $25^{\circ} \mathrm{C}$. Finally, samples were incubated with Hoechst 33342 (1:2,000; Invitrogen; Thermo Fisher Scientific, Inc.) for $5 \mathrm{~min}$ at $37^{\circ} \mathrm{C}$.

Images were captured using a confocal microscope (LSM700; Carl Zeiss AG) equipped with an oil immersion objective lens (magnification, $x 40$ ). Images were analyzed with ZEN 2012 (Carl Zeiss AG) and processed using ImageJ software ver.1.51 (National Institutes of Health) (29).

Irradiation. Cells were exposed to 5 or $8 \mathrm{~Gy} 150 \mathrm{kV}$ X-rays delivered at $0.57 \mathrm{~Gy} / \mathrm{min}$ using an MBR-1505R2 generator (Hitachi Ltd.). The beam was filtered through a $1-\mathrm{mm}$ aluminum board and the accuracy of irradiation was checked, as previously described (30).

Colony forming assay. Cell survival following irradiation was evaluated by performing a colony forming assay in the presence or absence of 10 or $20 \mu \mathrm{g}$ exosomes generated following $5 \mathrm{~Gy}$ irradiation (5 Gy-Exo). Cells were reseeded into 6-well cell culture plates (Corning, Inc.) at a density of 200-4,000 cells/well and incubated for 7-10 days (7-10 cell cycles) at $37^{\circ} \mathrm{C}$. The number of seeded cells was different in each group [control, $100 ; 5 \mathrm{~Gy}, 500 ; 5 \mathrm{~Gy}+5$ Gy-Exo $(5 \mu \mathrm{g} / \mathrm{ml}), 1,000$ and $5 \mathrm{~Gy}+$ 5 Gy-Exo $(10 \mu \mathrm{g} / \mathrm{ml}), 2,000 \mathrm{cells} / \mathrm{ml}]$ depending on the dose of irradiation. At the end of each experiment using non-irradiated exosomes (0 Gy-Exo) or 5 Gy-Exo, the cells were fixed with a solution of $10 \%$ methanol and $20 \%$ acetic acid for $30 \mathrm{~min}$ and stained at $25^{\circ} \mathrm{C}$. With methylene blue for $30 \mathrm{~min}$ as previously described (31). Colonies ( $\geq 50$ cells) were counted and the surviving fraction was determined based on the number of colonies per seeded cell.

Determination of intracellular ROS levels. Intracellular ROS levels were determined using the oxidation-sensitive fluorescent probe dye C- $\mathrm{H}_{2} \mathrm{DCF}$ (Invitrogen; Thermo Fisher Scientific, Inc.) as described previously (32). Cells were seeded in 6-well plates $\left(1.5 \times 10^{5}\right.$ cells $/$ well $)$ overnight at $37^{\circ} \mathrm{C}$ and treated with $5 \mathrm{~Gy}$ radiation in the presence or absence of $10 \mu \mathrm{g} / \mathrm{ml} 5 \mathrm{~Gy}$-Exo and $1 \mathrm{mM}$ NAC (Sigma Aldrich; Merck KGaA) for $24 \mathrm{~h}$ at $37^{\circ} \mathrm{C}$, as previously described (33). After washing twice with FBS-free media (MEM; Sigma Aldrich; Merck KGaA) the cells were stained with $50 \mu \mathrm{M} \mathrm{C}-\mathrm{H}_{2} \mathrm{DCF}$ for $1 \mathrm{~h}$ at $37^{\circ} \mathrm{C}$. The nuclei of cells were then stained with Hoechst 33342 (1:2,000; Invitrogen; Thermo Fisher Scientific, Inc.) for $5 \mathrm{~min}$ at $37^{\circ} \mathrm{C}$. The fluorescence of $\mathrm{C}-\mathrm{H}_{2} \mathrm{DCF}$ was visualized using a fluorescence microscope (magnification, x20) (BZ-9000; Keyence Corporation).

Detection of DNA damage following exosome uptake. Induction of DNA damage was investigated by detecting
$\gamma$-H2AX foci using immunocytochemistry, as described previously (34). Cells were seeded on 35-mm dishes and treated with $10 \mu \mathrm{g} / \mathrm{ml} 5$ Gy-Exo and $1 \mathrm{mM} \mathrm{NAC}$ for $24 \mathrm{~h}$ and/or $5 \mathrm{~Gy}$ irradiation at $25^{\circ} \mathrm{C}$. Then, the cells were fixed in 4\% paraformaldehyde in PBS for 20 min, permeabilized with $0.1 \%$ Triton X-100 in PBS for 5 min and blocked in 5\% BSA (Sigma-Aldrich; Merck KGaA) in PBS for $60 \mathrm{~min}$ at $25^{\circ} \mathrm{C}$. The cells were incubated with rabbit anti $\gamma$-H2AX antibody (1:200; Cell Signaling Technology, Inc.) overnight at $4^{\circ} \mathrm{C}$. The cells were then incubated with TRITC-conjugated secondary antibody (1:20; Dako; Agilent Technologies, Inc.) for $90 \mathrm{~min}$ at $25^{\circ} \mathrm{C}$. The nuclei were stained with DAPI (1:300; Invitrogen; Thermo Fisher Scientific, Inc.) for $10 \mathrm{~min}$ at $25^{\circ} \mathrm{C}$. The stained cells were observed using a fluorescence microscope (magnification, $\mathrm{x} 40$ ). The number of cells expressing nuclear $\gamma$-H2AX foci were then counted manually in 100 cells of each treatment group, as previously described (35).

Immunoblotting. The expression levels of CD9, CD63 and cytochrome $c$ were analyzed. Briefly, $3 \mu \mathrm{g}$ exosomes (0 and 5 Gy-Exo) were separated by 8 (CD9), 12 (CD63) or $15 \%$ (cytochrome $c$ ) SDS-PAGE gels in non-reducing conditions. A total of $30 \mu \mathrm{g}$ whole cell lysate was separated using RIPA buffer supplemented with protease inhibitor cocktail (Nacalai Tesque) previously described (36) in reducing conditions [boiling for $5 \mathrm{~min}$ at $95^{\circ} \mathrm{C}$ and addition of reducing agent, 5\% 2-Mercaptoethanol (FUJIFILM Wako Pure Chemical Corporation) at $\left.25^{\circ} \mathrm{C}\right]$ and transferred to a PVDF membrane. Membranes were blocked using 3 (cytochrome $c$ ) or $5 \%$ non-fat milk for $30 \mathrm{~min}$ at $25^{\circ} \mathrm{C}$, incubated with anti-CD9 (1:500), anti-CD63 (1:500) or anti-cytochrome $c(1: 1,000)$ antibodies overnight at $4^{\circ} \mathrm{C}$ and washed three times in Tris-buffered saline with 10\% Tween-20 (TBS-T). Subsequently, membranes were

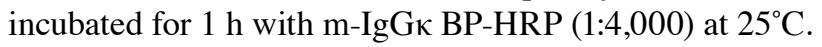

The expression levels of SOD1 and SOD2 in MIAPaCa-2 cells were analyzed. Briefly, cells were seeded at $1.0 \times 10^{5}$ cells/well in 6 -well plates and incubated overnight at $37^{\circ} \mathrm{C}$ and subjected to irradiation with $8 \mathrm{~Gy}$ or addition of $30 \mu \mathrm{g}$ 8 Gy-Exo at $25^{\circ} \mathrm{C}$. Proteins was collected using RIPA buffer supplemented with protease inhibitor cocktail (Nacalai Tesque) at $24 \mathrm{~h}$ after treatment. Quantification of proteins was proceeded using Qubit ${ }^{\mathrm{TM}}$ Protein Assay kit (Invitrogen; Thermo Fisher Scientific, Inc.). A total of $15 \mu \mathrm{g}$ protein/lane was separated by $10 \%$ SDS-PAGE and transferred to a PVDF membrane. Membranes were blocked using 5\% BSA (Sigma-Aldrich; Merch $\mathrm{KGaA}$ ) blocking buffer for $40 \mathrm{~min}$ at $25^{\circ} \mathrm{C}$, incubated with anti-SOD1 and anti-SOD2 (both 1:1,000) antibodies overnight at $4^{\circ} \mathrm{C}$ and then washed three times in $10 \%$ TBS-T. Subsequently, membranes were incubated for $1 \mathrm{~h}$ with rabbit anti-sheep IgG-HRP $(1: 2,000)$ secondary antibody at $25^{\circ} \mathrm{C}$. The secondary antibodies were visualized with $\mathrm{ECL}^{\mathrm{TM}}$ Prime Western Blotting Detection Reagents (GE Healthcare) using a gel imaging system with preconfigured Image Lab Touch software 5.2.1 (ChemiDoc Touch MP; Bio-Rad Laboratories, Inc.). Subsequently, the PVDF membranes were incubated with anti-actin $(1: 5,000)$ antibody overnight at $4^{\circ} \mathrm{C}$. After washing with TBS-T three times, membranes were incubated for $1 \mathrm{~h}$ with donkey anti-goat IgG, $\mathrm{F}\left(\mathrm{ab}^{\prime}\right)_{2}$-HRP secondary antibody at $25^{\circ} \mathrm{C}$, which was visualized as aforementioned. The intensity of each signal was analyzed using ImageJ software ver.1.51 
(National Institutes of Health) and the ratios of SOD1, SOD2 and actin levels were calculated.

Following $48 \mathrm{~h}$ transfection with miR-6823-5p-mimic, the expression levels of SOD1 were analyzed, as aforementioned. Protein concentrations were determined using a Qubit ${ }^{\mathrm{TM}}$ Protein Assay kit.

Total RNA extraction from exosomes and miRNA microarray analysis. Total RNA was extracted from exosomes using Toray's 3D-Gene RNA extraction reagent from a liquid sample kit (Toray Industries, Inc.). Comprehensive miRNA expression analysis was performed using a 3D-Gene miRNA Labeling kit and a 3D-Gene Human miRNA Oligo Chip Ver. 21 (Toray Industries, Inc.) according to the manufacturer's protocol to detect 2,565 human miRNA sequences. The expression levels of each miRNA were expressed as the background-subtracted signal intensity of all miRNAs in each microarray. Any signal intensity in both the duplicate spots at $>1.5 \mathrm{SD}$ of the background signal intensity was considered a valid measurement. The raw data are available in the Gene Expression Omnibus database (GSE163133).

Database processing analysis and miRNA identification. miRNAs from exosomes isolated from cells irradiated with either 5 or 8 Gy were visualized in the form of a heat map using R software (version 3.5.3; R-project.org) (37) and heatmap.2 from the gplots package (version 3.0.1.1; CRAN.R-project. org/pakage=gplots) (38). The heatmap presents Z-score values for miRNAs with ratios of expression values between control (exosomes from non-irradiated cells) and 5 or 8 Gy-Exo $<0.5$ or $>1.5$. In addition, TargetScan (targetscan.org/vert_72/) (39) and miRTarBase (mirtarbase.cuhk.edu.cn/php/index.php) (40) were searched for targets of these miRNAs that result in increased ROS levels. miRNAs data were then proceeded hierarchical clustering with Euclidean distance and complete linkage.

Transfection of miR mimics. In order to investigate the effect of miRNAs on intracellular ROS levels, mirVana ${ }^{\mathrm{TM}}$ miRNA (miR-6823-5p) mimics and negative control (Sigma-Aldrich; Merch $\mathrm{KGaA})$ were used. MIAPaCa- 2 cells $\left(2.2 \times 10^{5}\right.$ per well) were seeded in 24-well plates and transfected with $5 \mathrm{nM}$ miR-mimic or negative control using HiPerFect Transfection Reagent (Qiagen $\mathrm{GmbH}$ ) for $48 \mathrm{~h}$ at $25^{\circ} \mathrm{C}$. Cells were harvested at $37^{\circ} \mathrm{C}$ and the expression levels of mRNA and protein were examined $48 \mathrm{~h}$ after transfection at $25^{\circ} \mathrm{C}$. ROS levels and DNA damage in transfected cells were assessed as aforementioned. The mimic sequences were as follows: miR-6823-5p, 5'-UCA GGGUUGGUAGGGGUUGCU-3'; siRNA control 1, 5'-GGU UCGUACGUACACUGUUCA-3'; and siRNA control 2, 5'-CGGUACGAUCGCGGCGGGAUAUC-3'.

Reverse transcription-quantitative (RT- $q) P C R$. Total RNA for RT-qPCR was obtained from cell samples using a mirVana ${ }^{\mathrm{TM}}$ miRNA Isolation kit (Invitrogen; Thermo Fisher Scientific, Inc.) and reverse transcribed at $25^{\circ} \mathrm{C}$ for $30 \mathrm{~min}, 37^{\circ} \mathrm{C}$ for $2 \mathrm{~h}$, $85^{\circ} \mathrm{C}$ for $5 \mathrm{~min}$ and $4^{\circ} \mathrm{C}$ for $10 \mathrm{~min}$ to cDNA using the High Capacity cDNA Reverse Transcription kit (Applied Biosystems; Thermo Fisher Scientific, Inc.). RT-qPCR was performed using EagleTaq Universal Master Mix (ROX) (Roche Diagnostics) and TaqMan ${ }^{\circledR}$ Gene Expression Assays (Applied Biosystems;
Thermo Fisher Scientific, Inc.) using following TaqMan probe to SOD1 (cat. no. Hs00533490_m1). The thermocycling conditions were as follows: initial denaturation at $50^{\circ} \mathrm{C}$ for $2 \mathrm{~min}$ and $95^{\circ} \mathrm{C}$ for $10 \mathrm{~min}$, followed by $95^{\circ} \mathrm{C}$ for $15 \mathrm{sec}$ and 40 cycles at $60^{\circ} \mathrm{C}$ for $1 \mathrm{~min}$. Expression data of SOD1 was acquired and analyzed by the $2^{-\Delta \Delta \mathrm{Cq}}$ method (41) using a Thermal Cycler Dice ${ }^{\circledR}$ Real Time System III (Takara Bio, Inc.). All data were normalized to GAPDH (cat. no. Hs02786624_g1).

Statistical analysis. Data are presented as the mean \pm SEM of three independent experimental repeats. Differences between the means were compared using one-way ANOVA, followed by post hoc Tukey's test. $\mathrm{P}<0.05$ was considered to indicate a statistically significant difference.

\section{Results}

Characterization of exosomes. The purity, quality, and morphology of exosomes were analyzed. According to the result of measurement using Qubit Protein Assay kit, $\sim 1.67 \mu \mathrm{g} / \mathrm{ml}$ exosomes were collected from the culture medium. The isolated exosomes were shaped in the form of closed, round vesicles with a diameter of $\sim 100 \mathrm{~nm}$. The morphological features of 0 and 5 Gy-Exo were similar, as shown by TEM (Fig. 1A). CD9 and CD63 expression was observed in both whole cell lysate and exosomes, while cytochrome $c$ expression was detected only in the whole cell lysate (Fig. 1B). Distribution profiles for 0 and 5 Gy-Exo revealed peaks at 107 and $101 \mathrm{~nm}$, respectively, as assessed using NanoSight (Fig. 1C; Videos S1 and S2). These data indicated that the exosomes were successfully isolated from the culture media supernatant without contamination due to cellular components.

Cellular uptake of exosomes and survival. The uptake of 5 Gy-Exo was increased compared with that of 0 Gy-Exo (Fig. 2A). Cells were irradiated and treated in the presence or absence of 5 Gy-Exo (Fig. 2B). Cells irradiated with 5 Gy-Exo showed an increased radiosensitizing effect in an exosome concentration-dependent manner (Fig. 2C; Table SI).

Exosomes increase intracellular ROS levels. Intracellular ROS levels increased following addition of 0 or 5 Gy-Exo or irradiation with $5 \mathrm{~Gy}$; the highest levels were observed following combined irradiation and exosome treatment. Irradiation (5 Gy) combined with the addition of 0 Gy-Exo resulted in ROS levels similar to those for the irradiation-alone treatment group (Fig. 3). Intracellular ROS levels were significantly decreased following addition of the ROS scavenger NAC and these effects were dose-dependent (Figs. S1 and S2).

DNA damage is induced following exosome uptake. Addition of both 0 and 5 Gy-Exo increased the number of $\gamma-\mathrm{H} 2 \mathrm{AX}$ foci/cell, while combined irradiation and 5 Gy-Exo treatment significantly increased the number of $\gamma-\mathrm{H} 2 \mathrm{AX}$ foci further. Irradiation (5 Gy) and treatment with 0 Gy-Exo resulted in numbers of $\gamma-\mathrm{H} 2 \mathrm{AX}$ foci similar to that of the irradiation-alone group (Fig. 4). NAC treatment resulted in fewer $\gamma$-H2AX foci/cell, indicating that DNA damage was induced by an increase in ROS levels and these effects were dose-dependent (Figs. S2 and S3). 
A
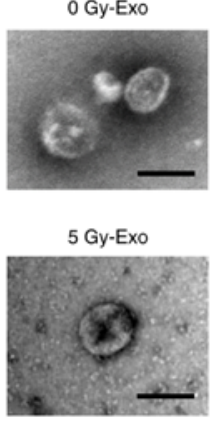

C

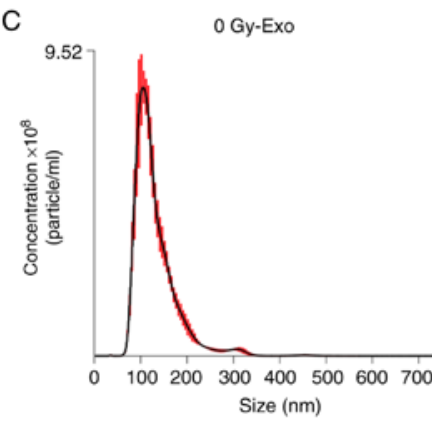

B
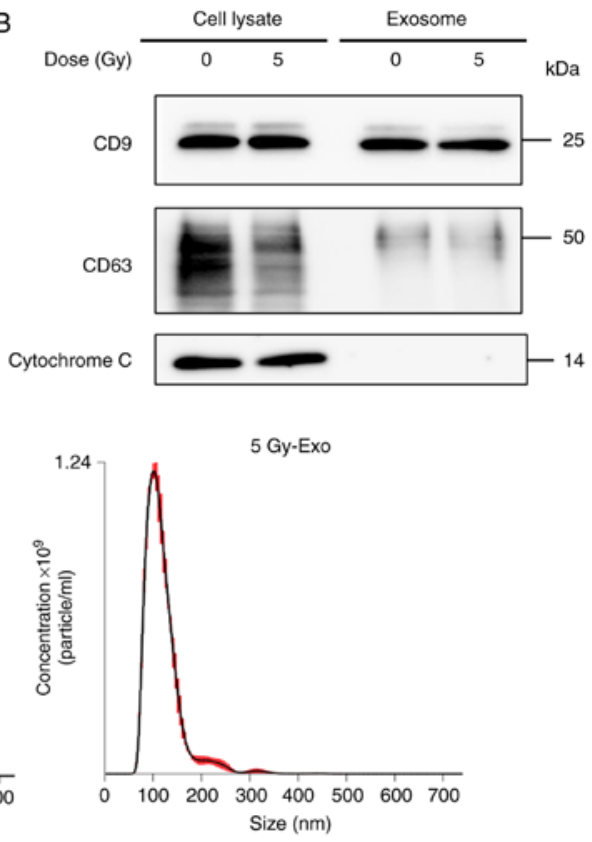

Figure 1. Typical features and characteristics of exosomes. (A) Transmission electron microscopy micrographs of exosomes isolated from non-irradiated and 5 Gy-irradiated MIAPaCa-2 cells. Scale bar, $100 \mathrm{~nm}$. (B) Western blot analysis of exosomal proteins CD9 and CD63 and cell protein cytochrome $c$. (C) Nanoparticle tracking analysis of 0 and 5 Gy-Exo. 5 Gy-Exo, exosomes derived from 5 Gy-irradiated cells; 0 Gy-Exo, exosomes derived from non-irradiated cells.

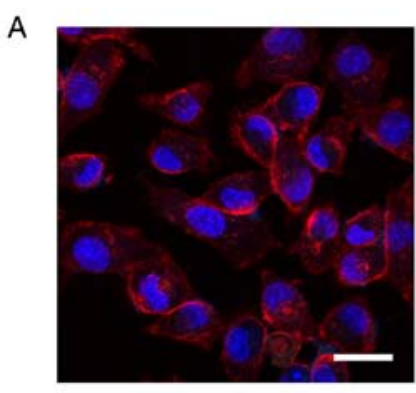

PBS

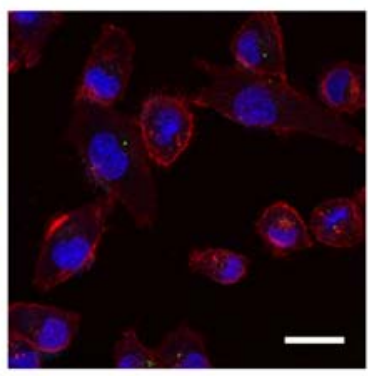

0 Gy-Exo

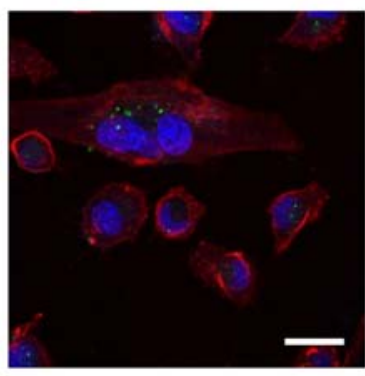

5 Gy-Exo

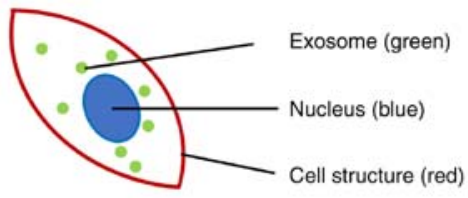

B

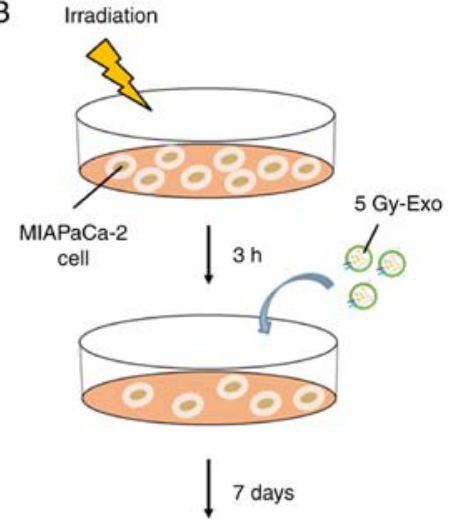

Colony-forming assay

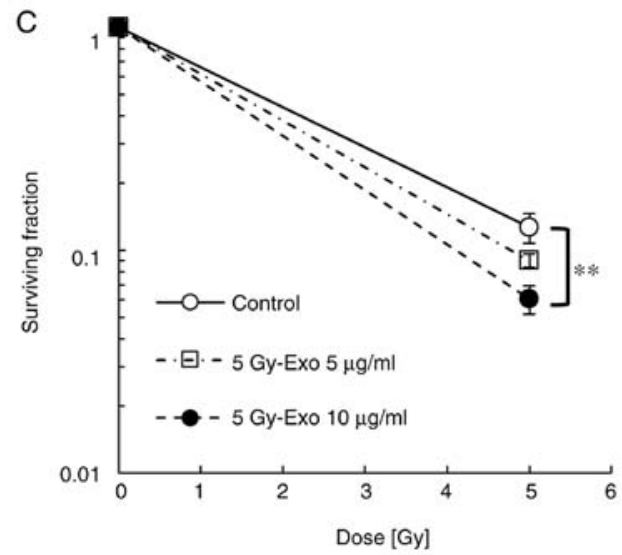

Figure 2. Interaction of exosomes with cancer cells. (A) Representative images showing 0 and 5 Gy-Exo uptake by MIAPaCa-2 cells under a confocal microscope. Uptake (green) of 5 Gy-Exo was greater than that of 0 Gy-Exo. Blue, Hoechst counterstaining. Scale bar, $20 \mu \mathrm{m}$. (B) Schema of colony forming assay following treatment with exosomes. (C) Survival fractions. Data are presented as the mean \pm SEM ( $n=3)$. P-values were calculated using one-way ANOVA, followed by post hoc Tukey's test. ${ }^{* *} \mathrm{P}<0.01 .5$ Gy-Exo, exosomes derived from 5 Gy-irradiated cells; 0 Gy-Exo, exosomes derived from non-irradiated cells. 

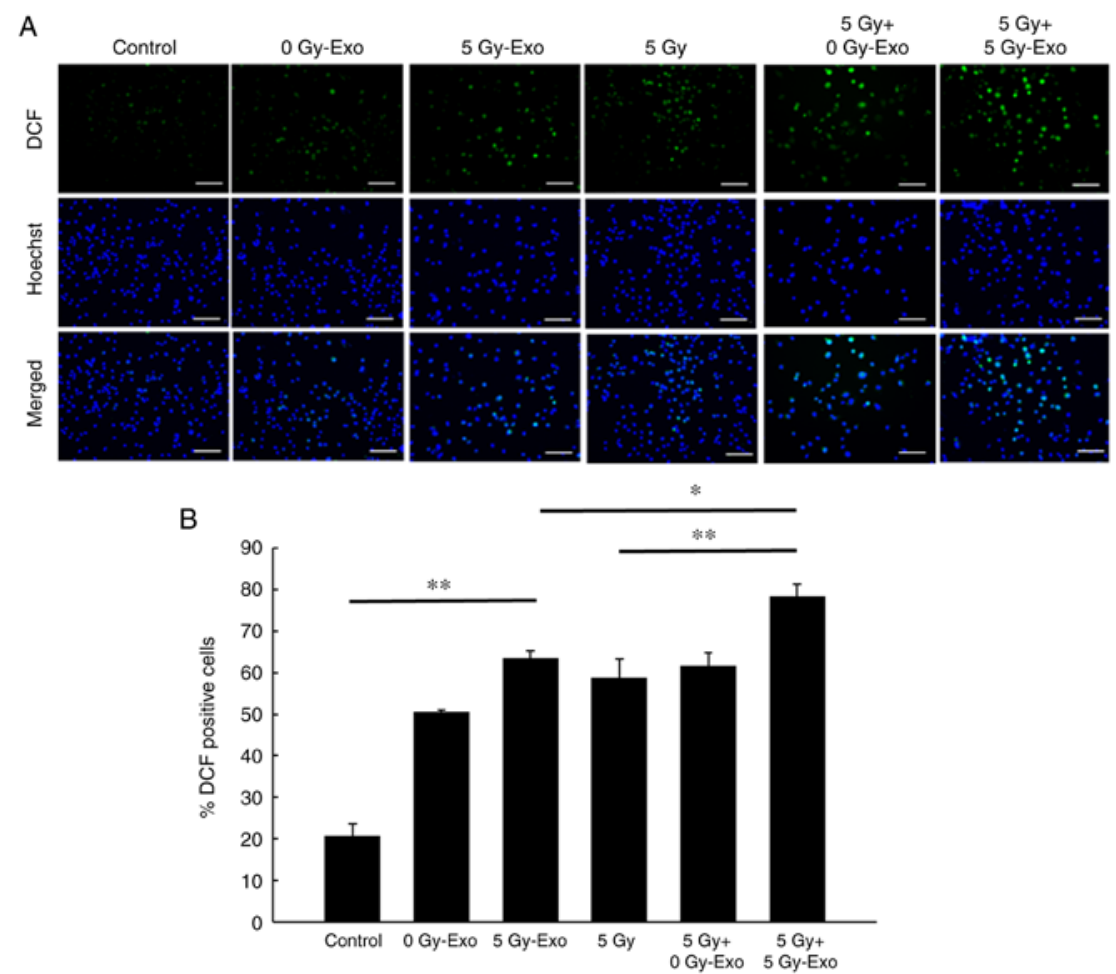

Figure 3. Intracellular ROS levels increase following addition of exosomes to cancer cells. (A) Intracellular ROS were identified by $\mathrm{C}-\mathrm{H}_{2} \mathrm{DCF}$ staining. Scale bar, $100 \mu \mathrm{m}$. (B) Ratio of C- $\mathrm{H}_{2}$ DCF-positive cells. The proportion of DCF-positive cells is presented as the mean \pm SEM from three fields of view/section. $\mathrm{P}$-values were calculated using one-way ANOVA, followed by post hoc Tukey's test. ${ }^{*} \mathrm{P}<0.05,{ }^{* *} \mathrm{P}<0.01$. ROS, reactive oxygen species; $\mathrm{C}-\mathrm{H}_{2} \mathrm{DCF}, 2^{\prime}, 7^{\prime}-\mathrm{dichlor}$ odihydrofluorescein diacetate; 5 Gy-Exo, exosomes derived from 5 Gy-irradiated cells; 0 Gy-Exo, exosomes derived from non-irradiated cells.

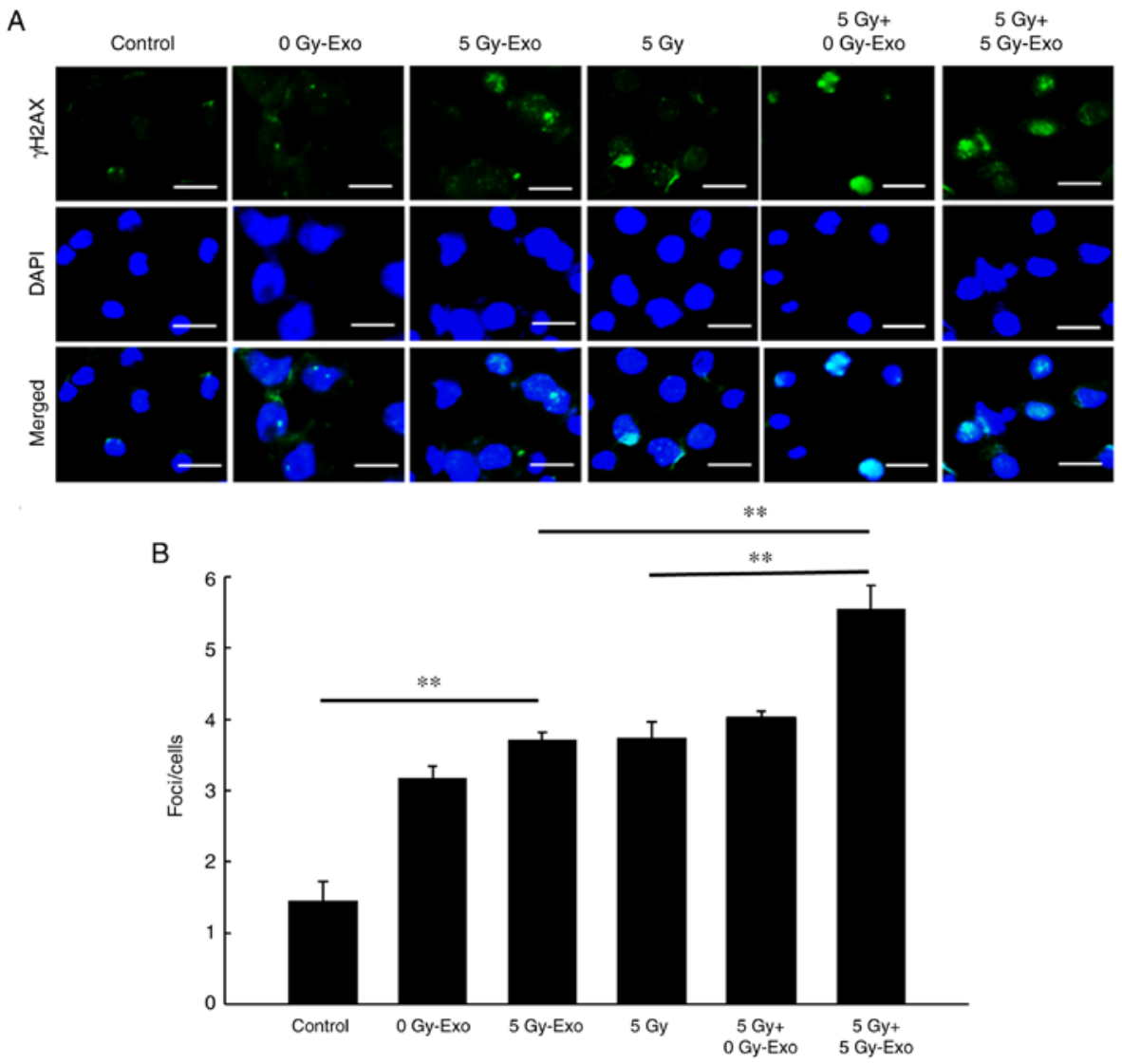

Figure 4. DNA damage increases following addition of exosomes to cancer cells. (A) Representative images of cells with DNA damage identified by $\gamma$-H2AX foci (green) and counterstaining with DAPI (blue). Scale bar, $20 \mu \mathrm{m}$. (B) Number of $\gamma$-H2AX foci/cell was calculated as the mean \pm SEM from three fields of view/section. P-values were calculated using one-way ANOVA, followed by post hoc Tukey's test. ${ }^{* *} \mathrm{P}<0.01 . \gamma$-H2AX, phosphorylated histone $2 \mathrm{AX}$; 5 Gy-Exo, exosomes derived from 5 Gy-irradiated cells; 0 Gy-Exo, exosomes derived from non-irradiated cells. 

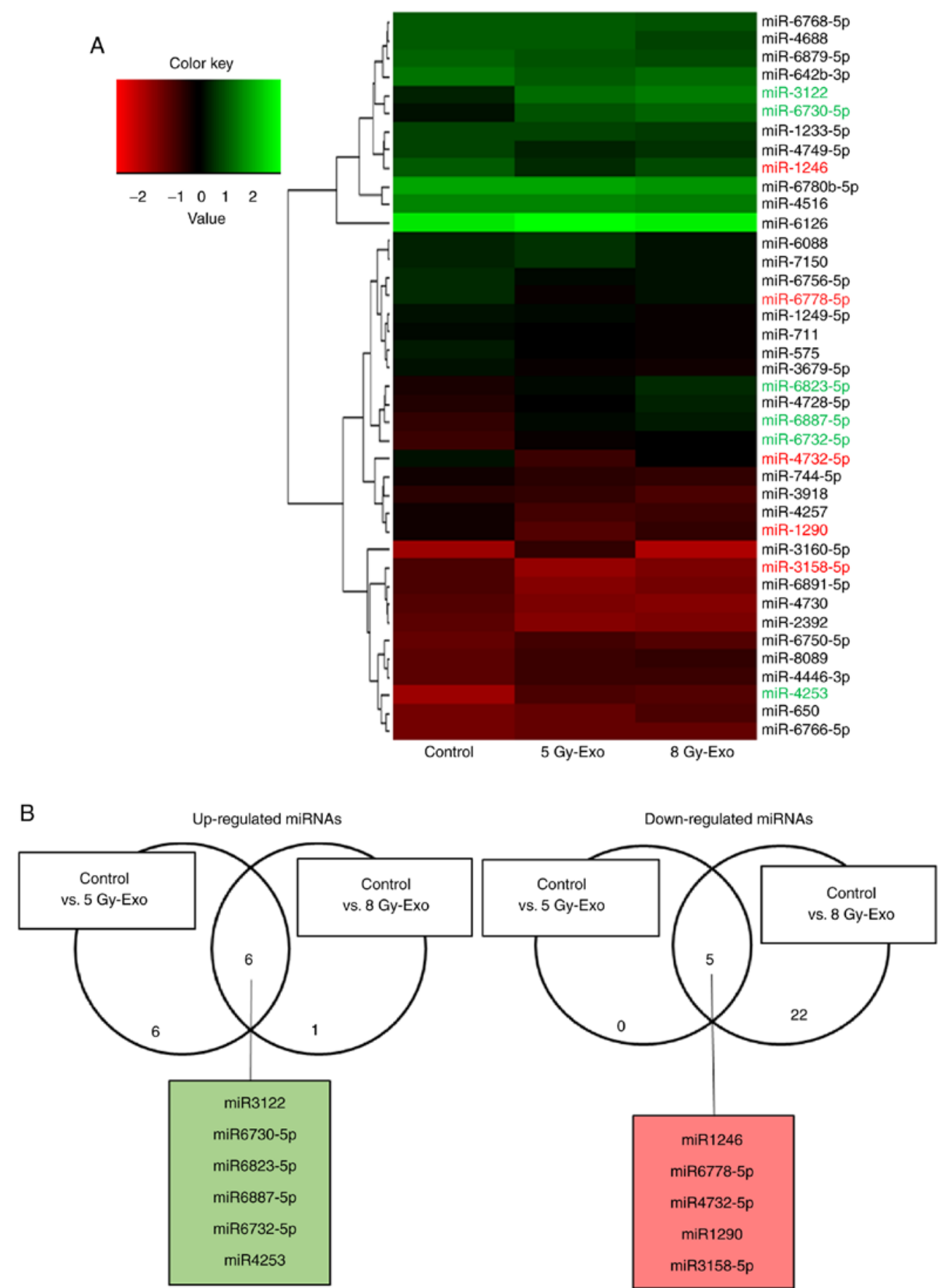

Figure 5. miRNA expression levels in 5 and 8 Gy-Exo compared with 0 Gy-Exo control. (A) Heat map showing the normalized expression levels of miRNAs in 0,5 and 8 Gy-Exo. (B) Venn diagram of distribution of miRNAs in 5 and 8 Gy-Exo samples using the ratio of expression with control. 5 Gy-Exo, exosomes derived from 5 Gy-irradiated cells; 8 Gy-Exo, exosomes derived from 8 Gy-irradiated cells; 0 Gy-Exo, exosomes derived from non-irradiated cells.

Identification of miRNA in exosomes following irradiation. The differential expression levels of miRNAs in 5 and 8 Gy-Exo compared with 0 Gy-Exo were stratified using a heat map (Fig. 5A). A total of six up- and five downregulated microRNA in both 5 and 8 Gy-Exo were identified (Fig. 5B). TargetScan and miRTarBase were used to identify potential targets of these miRNAs that may be associated with increased ROS levels. miR-6823-5p was identified as a potential candidate for SOD1 inhibition and subsequent analysis confirmed the inhibitory effect of miR-6823-5p (Fig. 6).
Exosomes inhibit SOD1 expression levels in cancer cells. Cells were treated with $8 \mathrm{~Gy}$ irradiation or addition of $8 \mathrm{~Gy}$-Exo, then the expression levels of antioxidant enzymes including SOD1 and SOD2 were analyzed. SOD1 expression notably decreased following addition of 8 Gy-Exo, but SOD2 expression levels did not change (Fig. 6A). Using TargetScan, the complementary sequence site of SOD1 was found to correspond with miR-6823-5p (Fig. 6B). SOD1 expression levels decreased following transfection with an miR-6823-5p-mimic (Fig. 6C). Additionally, the relative cDNA level of SOD1 in cells transfected 

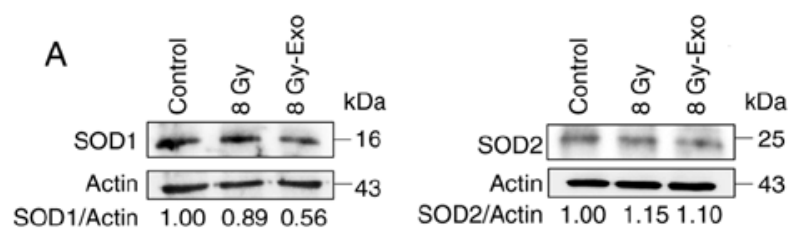

B

299-305 of SOD1 3' UTR 5' AA GCCUGUGAAUAAAACCCUGU miR-6823-5p 3' UCGUUGGGGAUGGUUGGGACU

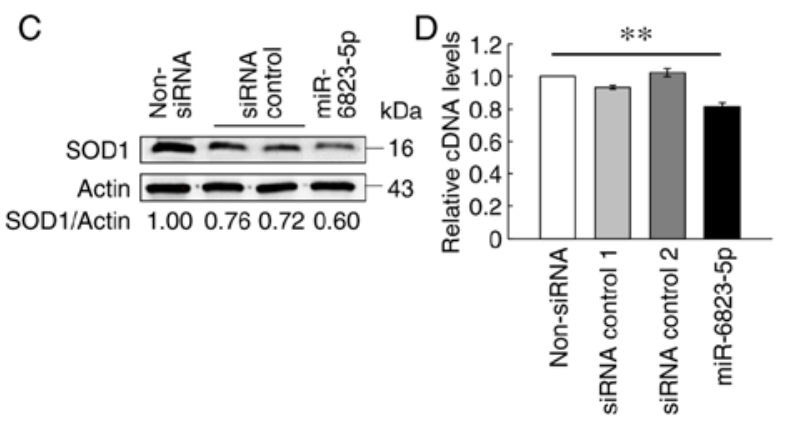

Figure 6. Addition of 8 Gy-Exo to cancer cells decreases SOD1 expression levels. (A) Expression levels of antioxidant enzymes SOD1 and SOD2 in MIAPaCa-2 cells following irradiation with 8 Gy or 8 Gy-Exo addition were analyzed by western blotting. The ratio of antioxidant enzyme and actin expression levels was calculated by gray intensities. (B) Complementary sequence site of SOD1 and miR-6823-5p. (C) Western blot analysis of SOD1 expression levels in transfected MIAPaCa-2 cells. Ratio of SOD1 and actin expression levels was calculated by gray intensities. (D) Relative cDNA levels of SOD1 were determined by reverse transcription-quantitative PCR. Data are presented as the mean \pm SEM $(n=3)$. P-values were calculated using one-way ANOVA, followed by post hoc Tukey's test. ${ }^{* *} \mathrm{P}<0.01$. 8 Gy-Exo, exosomes derived from 8 Gy-irradiated cells; SOD1, $\mathrm{Cu} / \mathrm{Zn}$ superoxide dismutase enzyme; SOD2, Mn-superoxide dismutase enzyme; miR, microRNA; UTR, untranslated region; si, short interfering.

with miR-6823-5p-mimic significantly decreased compared with that of non-transfected cells (non-siRNA), although that of cells transfected with siRNA control 1 and 2 did not change significantly. (Fig. 6D). Taken together, these results suggest that miR-6823-5p in exosomes derived from irradiated cells may contribute to decreased SOD1 expression levels.

miR-6823-5p mimics increase ROS levels and DNA damage in MIAPaCa-2 cells. ROS levels and DNA damage, which significantly increased in cells transfected with miR-6823-5p mimic, decreased significantly following the addition of NAC (Figs. 7 and 8). These results confirmed that miR-6823-5p increased intracellular ROS levels, leading to DNA damage in MIAPaCa-2 cells.

\section{Discussion}

The aim of the present study was to investigate whether irradiated exosomes induce intracellular increases in ROS levels in neighboring cancer cells, leading to amplification of the radiation effect. The potential underlying mechanisms may be associated with transportation of certain miRNAs from irradiated cancer cells via exosomes. To the best of our knowledge, the present study is the first to report that miR-6823-5p may function as an inhibitor of SOD1 expression in response to radiation.
SOD1, which is overexpressed in several types of cancer cell, such as breast (42) and non-small lung cancer cells (43) may be essential for the maintenance of cellular ROS levels. Papa et al (44) reported that SOD1 serves an important role in cancer progression and described a potential association between SOD1 overexpression and regulation of the mitochondrial unfolded-protein response. Cells must continuously contend with extensive intracellular oxidative stress generated by ROS and reactive nitrogen species (RNS) (45). In order to control the genotoxic effects of ROS/RNS and their diverse functions (including signaling), cells regulate their levels via antioxidants, including SOD (46). Gomes et al (47) demonstrated that the expression of SOD1 is decreased in HCT116 colon cancer cells overexpressing miR-143 or miR-145. Furthermore, miR-143 overexpression increased ROS levels, which was abrogated by the reintroduction of SOD1. However, an increase in the levels of miR-143 and miR-145 in exosomes in the MIAPaCa-2 human pancreatic cancer cell line was not observed in the present study. This may be because the present study investigated miRNAs in exosomes obtained following radiation exposure. Moreover, the different sources of miRNAs may impact the results as the aforementioned study used a cancer cell line, whereas, here, exosomes were used in addition to a cancer cell line.

To the best of our knowledge, inhibition of SOD1 expression by exosomes has not been reported previously. Furthermore, no studies have yet reported that exosomes from irradiated cells induce DNA damage via increasing ROS levels. These findings are important for investigating exosome functions in response to radiation. Glasauer et al (48) showed that inhibition of SOD1 expression, either via small hairpin RNA (shRNA) or a SOD1 inhibitor (ATN-224), notably decreases the ability of the lung carcinoma cell line A549 to form colonies on soft agar. They further reported that inhibition of SOD1 expression leads to an increase, rather than decrease, in $\mathrm{H}_{2} \mathrm{O}_{2}$ levels as a result of the inhibition of the glutathione peroxidase enzymes by superoxide; this suggested that the inhibition of SOD1 induces cell death by apoptosis (48). Taken together, the results of the present study indicate that SOD1 modulation may be a promising target for enhancing the radiation effect.

The present findings describe a novel mechanism associated with RIBE, which is involved in induction of DNA damage (49) and mutations $(50,51)$, cell death or apoptosis (52) and altered gene expression $(13,24)$ and miRNA profiles $(53,54)$. Here, 0 Gy-Exo induced ROS and DNA damage, potentially owing to higher concentrations of exosomes. The total amount of protein in the exosomes in the culture media without any treatment was $\sim 1.67 \mu \mathrm{g} / \mathrm{ml}$. For each ROS/DNA-damage experiment, $10 \mu \mathrm{g} / \mathrm{ml}$ exosomes, a 5 -fold higher concentration of exosomes compared with that in the culture medium, was administered. Therefore, larger amounts of $0 \mathrm{~Gy}$-Exo composites, such as proteins, lipids, cDNA and miRNA, may have been involved. It was speculated that these composites of 0 Gy-Exo may increase intracellular ROS levels, leading to DNA damage. Ionizing radiation is frequently accompanied by marked changes in the miRNA expression profile of cells $(55,56)$. Although miRNAs have been implicated in regulation of ROS levels via regulation of enzymes involved in ROS metabolism (57), the association between exogenous ROS and intercellular communication via exosomes has not 


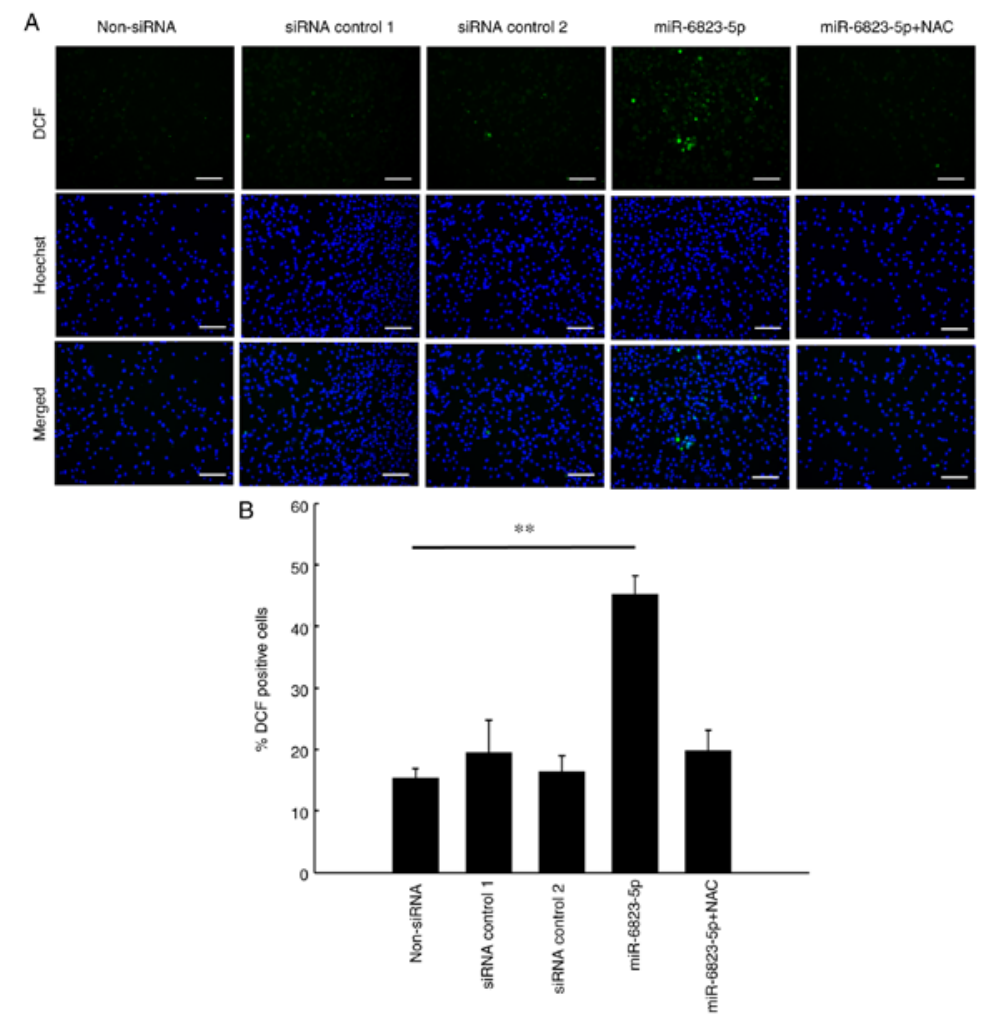

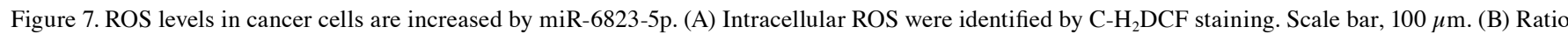
of C- $\mathrm{H}_{2} \mathrm{DCF}-$ positive cells. The proportion of DCF-positive cells was calculated as the mean $\pm \mathrm{SEM}$ from three fields of view/section. P-values were calculated using one-way ANOVA, followed by post hoc Tukey's test. * ${ }^{* *}<0.01$. ROS, reactive oxygen species; miR, microRNA; C- $\mathrm{H}_{2} \mathrm{DCF}, 2^{2}, 7^{\prime}-$ dichlorodihyd rofluorescein diacetate; NAC, N-acetyl-L-cysteine; si, short interfering.

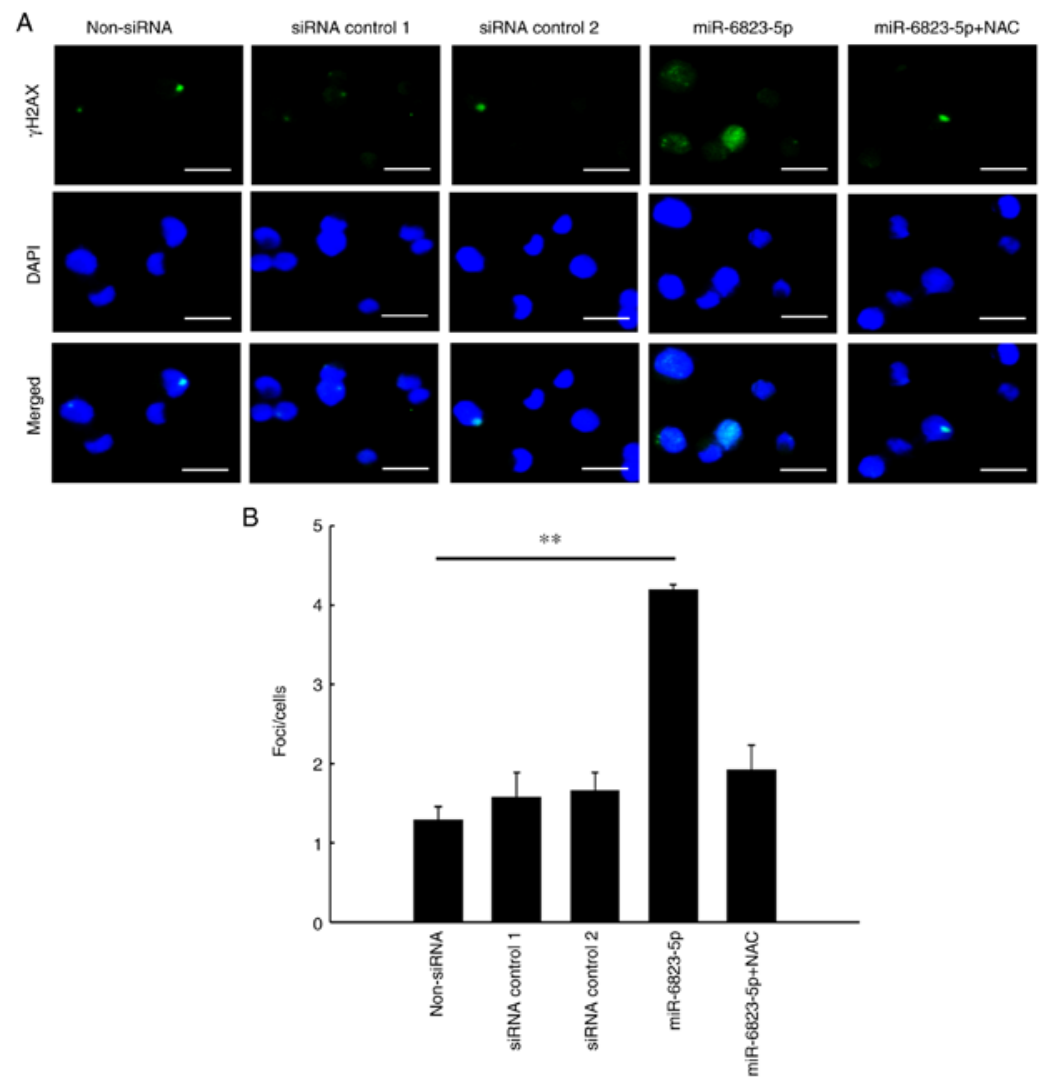

Figure 8. DNA damage in cancer cells is increased by miR-6823-5p. (A) Representative images of cells with DNA damage identified by $\gamma-\mathrm{H} 2 \mathrm{AX}$ foci (green) and counterstaining with DAPI (blue). Scale bar, $20 \mu \mathrm{m}$. (B) Number of $\gamma$-H2AX foci/cell was calculated as the mean \pm SEM from three fields of view/section. P-values were calculated using one-way ANOVA, followed by post hoc Tukey's test. ${ }^{* *} \mathrm{P}<0.01$. miR, microRNA; $\gamma$-H2AX, phosphorylated histone $2 \mathrm{AX}$; si, small interfering; NAC, N-acetyl-L-cysteine. 
been previously elucidated. In the present study, miR-6823-5p induced radiosensitive effects via inhibition of SOD1 expression. The difference in miR-6823-5p expression levels between the 0 and 5 Gy-Exo groups affected the enhancement of ROS level and DNA damage. ROS and DNA damage induced by X-ray radiation, and they affect cell survival or death signaling cascades $(58,59)$. Cancer cell-derived exosomes have demonstrated a role in promoting cancer cell invasiveness and metastasis, as well as activation of oncogenic pathways $(60,61)$.

The present study investigated intercellular communication between cancer cells via exosomes, which may be involved in other types of communication; between cancer and non-malignant cells, such as stromal, vascular and immune cells. Cancer cell-secreted exosomes affect other cancer or host cells and may lead to the secretion of additional exosomes from non-malignant cells (62). The present study confirmed increased uptake of exosomes generated from irradiated MIAPaCa-2 cells. It was hypothesized that irradiation induces this uptake by recipient cells although the underlying process remains unclear. Mutschelknaus et al (63) reported that radiation increases exosome release and uptake in head and neck squamous carcinoma cells and confirmed the influence of radiation on the uptake of exosomes using fluorescence-labeled exosomes. Arscott et al (64) used glioblastoma cell lines and reported that cellular irradiation increases exosome release and that radiation-derived exosomes are more readily taken up by recipient cells. These results are in accordance with increased uptake of exosomes by irradiated glioblastoma cells, which is facilitated by enhancement of cellular attachment to exosomes via augmented CD29/CD81 complex formation (65). Evidence indicates that exosomes mediate the delivery of proteins, mRNAs and miRNAs from cancer cells to recipient or neighboring cells by intercellular communication, which may assist in the creation of a metastatic niche and facilitate cancer cell progression and metastasis or influence the activity and/or behaviors of recipient cells $(66,67)$. The results of the current study regarding SOD1 inhibition serve as a basis for further investigation of novel roles associated with exosomes.

Limitations of the present study include the use of a single cell line (MIAPaCa-2 cells) and the lack of comparisons with other cell lines of the same origin. Thus, further investigations using other cell lines are needed for validation. In addition, exosome release may be affected by the range of radiation; effects of radiations in the $\mathrm{kV}$ and $\mathrm{MV}$ range may be different. However, radiation apparatus was only available for the $\mathrm{kV}$ range, not the MV range. Therefore, future studies should evaluate and compare the effects of $\mathrm{kV}$ - and $\mathrm{MV}$-range radiation on exosome release.

In conclusion, the present study identify a novel function of irradiated exosomes in terms of their ability to enhance the radiation effect via increasing intracellular ROS levels in cancer cells. The results contribute to the current understanding of the bystander effect between neighboring cancer cells.

\section{Acknowledgements}

The authors would like to thank Professor Ryo Nitta and Dr Tsuyoshi Imasaki of Division of Structural Medicine and Anatomy, Department of Physiology and Cell Biology,
Kobe University Graduate School of Medicine, for their helpful advice regarding TEM imaging. Parts of the data were presented at the 7th Japan-Taiwan Radiation Oncology symposium, Tokyo, Japan, May 112019.

\section{Funding}

The present study was supported by Grants-in-Aid for Exploratory Research (grant nos. 18K07752, 19K08097 and 08K07676) from the Ministry of Education, Culture, Sports, Science, and Technology of Japan.

\section{Availability of data and materials}

The datasets used and/or analyzed during the current study are available in the GEO repository, accession no. GSE163133, ncbi.nlm.nih.gov/geo/query/acc.cgi?acc=GSE163133.

\section{Authors' contributions}

AN, SI, HA and RS conceptualized and designed the study. AN, MN, MS, YF, HK, MH, NM, RN, TI, DM, TS and RS collected, analyzed and interpreted the data. AN, HK and RS drafted and critically revised the manuscript for important intellectual content. All authors read and approved the final version of the manuscript.

\section{Ethics approval and consent to participate}

Not applicable.

\section{Patient consent for publication}

Not applicable.

\section{Competing interests}

The authors declare that they have no competing interests.

\section{References}

1. Tkach M and Théry C: Communication by extracellular vesicles: Where we are and where we need to go. Cell 164: 1226-1232, 2016.

2. Hessvik NP and Llorente A: Current knowledge on exosome biogenesis and release. Cell Mol Life Sci 75: 193-208, 2018.

3. Greening DW, Gopal SK, Xu R, Simpson RJ and Chen W: Exosomes and their roles in immune regulation and cancer. Semin Cell Dev Biol 40: 72-81, 2015.

4. Yankovskaya V, Horsefield R, Törnroth S, Chavez CL, Miyoshi H, Léger C, Byrne B, Cecchini G and Iwata S: Architecture of succinate dehydrogenase and reactive oxygen species generation. Science 299: 700-704, 2003.

5. Nùkhet AB, Iman MA, Yueming Z, Larry WO and Douglas RS: Increased levels of superoxide and hydrogen peroxide mediate the differential susceptibility of cancer cells vs. normal cells to glucose deprivation. Biochem J 418: 29-37, 2009.

6. Szatrowski TP and Nathan CF: Production of large amounts of hydrogen peroxide by human tumor cells. Cancer Res 51: 794-798, 1991.

7. Boonstra $\mathrm{J}$ and Post JA: Molecular events associated with reactive oxygen species and cell cycle progression in mammalian cells. Gene 337: 1-13, 2004.

8. Miao L and St Clair DK: Regulation of superoxide dismutase genes: Implications in disease. Free Radic Biol Med 47: 344-356, 2009. 
9. Srinivas US, Tan BWQ, Vellayappan BA and Jeyasekharan AD ROS and the DNA damage response in cancer. Redox Biol 25: 101084, 2019.

10. Zou Z, Chang H, Li H and Wang S: Induction of reactive oxygen species: An emerging approach for cancer therapy. Apoptosis 22: 1321-1335, 2017.

11. Mukubou $\mathrm{H}$, Tsujimura $\mathrm{T}$, Sasaki $\mathrm{R}$ and $\mathrm{Ku} \mathrm{Y}$ : The role of autophagy in the treatment of pancreatic cancer with gemcitabine and ionizing radiation. Int $\mathrm{J}$ Oncol 37: 821-828, 2010.

12. Doskey CM, Buranasudja V, Wagner BA, Wilkes JG, Du J, Cullen JJ and Buettner GR: Tumor cells have decreased ability to metabolize $\mathrm{H}_{2} \mathrm{O}_{2}$ : Implications for pharmacological ascorbate in cancer therapy. Redox Biol 10: 274-284, 2016.

13. Shea A, Harish V, Afzal Z, Chijioke J, Kedir H, Dusmatova S, Roy A, Ramalinga M, Harris B, Blancato J, et al: MicroRNAs in glioblastoma multiforme pathogenesis and therapeutics. Cancer Med 5: 1917-1946, 2016.

14. Bracken CP, Scott HS and Goodall GJ: A network-biology perspective of microRNA function and dysfunction in cancer Nat Rev Genet 17: 719-732, 2016.

15. Di Francesco A, De Pittà C, Moret F, Barbieri V, Celotti L and Mognato M: The DNA-damage response to $\gamma$-radiation is affected by miR-27a in A549 cells. Int J Mol Sci 14: 17881-17896, 2013.

16. Zhang B, Chen J, Ren Z, Chen Y, Li J, Miao X, Song Y, Zhao T, Li Y, Shi Y, et al: A specific miRNA signature promotes radioresistance of human cervical cancer cells. Cancer Cell Int 13: 118 2013.

17. Shin S, Cha HJ, Lee EM, Lee SJ, Seo SK, Jin HO, Park IC, Jin YW and An S: Alteration of miRNA profiles by ionizing radiation in A549 human non-small cell lung cancer cells. Int J Oncol 35: 81-86, 2009.

18. Simone BA, Ly D, Savage JE, Hewitt SM, Dan TD, Ylaya K, Shankavaram U, Lim M, Jin L, Camphausen K, et al: MicroRNA alterations driving acute and late stages of radiation-induced fibrosis in a murine skin model. Int J Radiat Oncol Biol Phys 90 44-52, 2014.

19. Hou J, Wang F, Kong P, Yu PK, Wang H and Han W: Gene profiling characteristics of radioadaptive response in AG01522 normal human fibroblasts. PLoS One 10: e0123316, 2015

20. Sharma V and Misteli T: Non-coding RNAs in DNA damage and repair. FEBS Lett 587: 1832-1839, 2013.

21. Zhang $\mathrm{C}$ and Peng G: Non-coding RNAs: An emerging player in DNA damage response. Mutat Res 763: 202-211, 2015.

22. Lyng FM, Maguire P, McClean B, Seymour C and Mothersill C: The involvement of calcium and MAP kinase signaling pathways in the production of radiation-induced bystander effects. Radiat Res 165: 400-409, 2006.

23. Iyer R, Lehnert BE and Svensson R: Factors underlying the cell growth-related bystander responses to alpha particles. Cancer Res 60: 1290-1298, 2000.

24. Gow MD, Seymour CB, Ryan LA and Mothersill CE: Induction of bystander response in human glioma cells using high-energy electrons: A role for TGF-beta1. Radiat Res 173: 769-778, 2010.

25. Al-Mayah AHJ, Irons SL, Pink RC, Carter DRF and Kadhim MA: Possible role of exosomes containing RNA in mediating nontargeted effect of ionizing radiation. Radiat Res 177: 539-545, 2012.

26. JCRB Cell Bank: Cell information. Available from: cellbank. nibiohn.go.jp/ cellbank/cgi-bin/search_res_det.cgi?ID=245.

27. Thery C, Amigorena S, Raposo G and Clayton A: Isolation and characterization of exosomes from cell culture supernatants and biological fluids. Curr Protoc Cell Biol Chapter 3: Unit 3.22, 2006.

28. Pegtel DM, Cosmopoulos K, Thorley-Lawson DA, van Eijndhoven MA, Hopmans ES, Lindenberg JL, de Gruijl TD Würdinger T and Middeldorp JA: Functional delivery of viral miRNAs via exosomes. Proc Natl Acad Sci USA 107: 6328-6333, 2010.

29. Rasband WS: ImageJ, U.S. Available from: https://imagej.nih. gov/ij/, 1997-2018.

30. Shimizu Y, Mukumoto N, Idrus N, Akasaka H, Inubushi S, Yoshida K, Mikawaki D, Ishihara T, Okamoto Y, Yasuda T, et al: Amelioration of radiation enteropathy by dietary supplementation with reduced coenzyme Q10. Adv Radiat Oncol 4: 237-245, 2019.

31. Achanta G, Sasaki R, Feng L, Carew JS, Lu W, Pelicano H, Keating MJ and Huang P: Novel role of p53 in maintaining mitochondrial genetic stability through interaction with DNA Pol gamma. EMBO J 24: 3482-3492, 2005.
32. Dutta S, Warshall C, Bandyopadhyay C, Dutta D and Chandran B Interactions between exosomes from breast cancer cells and primary mammary epithelial cells leads to generation of reactive oxygen species which induce DNA damage response, stabilization of p53 and autophagy in epithelial cells. PLoS One 9: e97580, 2014.

33. Sasaki R, Suzuki Y, Yonezawa Y, Ota Y, Okamoto Y, Demizu Y, Huang P, Yoshida H, Sugimura K and Mizushina Y: DNA polymerase gamma inhibition by vitamin $\mathrm{K} 3$ induces mitochondria-mediated cytotoxicity in human cancer cells. Cancer Sci 99 1040-1048, 2008.

34. Nakayama M, Sasaki R, Ogino C, Tanaka T, Morita K, Umetsu M, Ohara S, Tan Z, Nishimura Y, Akasaka H, et al: Titanium peroxide nanoparticles enhanced cytotoxic effects of X-ray irradiation against pancreatic cancer model through reactive oxygen species generation in vitro and in vivo. Radiat Oncol 11: 91, 2016.

35. Bonner WM, Redon CE, Dickey JS, Nakamura AJ, Sedelnikova OA, Solier S and Pommier Y: GammaH2AX and cancer. Nat Rev Cancer 8: 957-967, 2008.

36. Inubushi S, Kawaguchi H, Mizumoto S, Kunihisa T, Baba M, Kitayama Y, Takeuchi T, Hoffman RM, Tanino H and Sasaki R: Oncogenic miRNAs identified in tear exosomes from metastatic breast cancer patients. Anticancer Res 40: 3091-3096, 2020.

37. R Core Team (2018): R: A language and environment for statical computing, 2018

38. Warnes GR, Bolker B, Bonebakker L, Gentleman R, Huber W, Liaw A, Lumley T, Maechler M, Magnusson A and Moeller S: gplots: Various R programming tools for plotting data, 2018.

39. Agarwal V, Bell GW, Nam J and Bartel DP: Predicting effective microRNA target sites in mammalian mRNAs. ELife 4: e05005, 2015.

40. Hsu SD, Lin FM, Wu WY, Liang C, Huang WC, Chan WL, Tsai WT, Chen GZ, Lee CJ, Chiu CM, et al: miRTarBase: A database curates experimentally validated microRNA-target interactions. Nucleic Acids Rese 39: 163-169, 2011.

41. Livak KJ and Schmittgen TD: Analysis of relative gene expression data using real-time quantitative PCR and the 2(-Delta Delta C(T)) method. Methods 25: 402-408, 2001

42. Gomez ML, Shah N, Kenny CT, Jenkins CE Jr and Germain D: SOD1 is essential for oncogene-driven mammary tumor formation but dispensable for normal development and proliferation. Oncogene 38: 5751-5765, 2019.

43. Liu S, Li B, Xu J, Hu S, Zhan N, Wang H, Gao C, Li J and Xu X: SOD1 promotes cell proliferation and metastasis in non-small cell lung cancer via an miR-409-3p/SOD1/SETDB1 epigenetic regulatory feedforward loop. Front Cell Dev Biol 8: 213, 2020.

44. Papa L, Manfredi G and Germain D: SOD1, an unexpected novel target for cancer therapy. Genes Cancer 5: 15-21, 2014.

45. Valko M, Rhodes CJ, Moncol J, Izakovic M and Mazur M: Free radicals, metals and antioxidants in oxidative stress-induced cancer. Chem Biol Interact 160: 1-40, 2006.

46. Koskenkorva-Frank ST, Weiss G, Koppenol HW and Burckhardt S: The complex interplay of iron metabolism, reactive oxygen species, and reactive nitrogen species: Insights into the potential of various iron therapies to induce oxidative and nitrosative stress. Free Radic Biol Med 65: 1174-1194, 2013.

47. Gomes SE, Pereira DM, Roma-Rodrigues C, Fernandes AR, Borralho PM and Rodrigues CM: Convergence of miR-143 overexpression, oxidative stress and cell death in HCT116 human colon cancer cells. PLoS One 13: e0191607, 2018.

48. Glasauer A, Sena LA, Diebold LP, Mazar AP and Chandel NS: Targeting SOD1 reduces experimental non-small-cell lung cancer. J Clin Invest 124: 117-128, 2013.

49. Yang H, Assad N and Held KD: Medium-mediated intercellular communication is involved in bystander responses of X-ray-irradiated normal human fibroblasts. Oncogene 24: 2096-2103, 2005

50. Zhou H, Randers-Pehrson G, Waldren CA, Vannais D, Hall EJ and Hei TH: Induction of a bystander mutagenic effect of alpha particles in mammalian cells. Proc Natl Acad Sci USA 97: 2099-2104, 2000.

51. Huo L, Nagasawa H and Little JB: HPRT mutants induced in bystander cells by very low fluences of alpha particles result primarily from point mutations. Radiat Res 156: 521-525, 2001.

52. Lyng FM, Seymour CB and Mothersill C: Initiation of apoptosis in cells exposed to medium from the progeny of irradiated cells: A possible mechanism for bystander-induced genomic instability? Radiat Res 157: 365-370, 2002. 
53. Kovalchuk O, Zemp FJ, Filkowski JN, Altamirano AM Dickey JS, Jenkins-Baker G, Marino SA, Brenner DJ, Bonner WM and Sedelnikova OA: MicroRNAome changes in bystander three-dimensional human tissue models suggest priming of apoptotic pathways. Carcinogenesis 31: 1882-1888, 2010.

54. Koturbash I, Zemp F, Kolb B and Kovalchuk O: Sex-specific radiation-induced microRNAome responses in the hippocampus, cerebellum and frontal cortex in a mouse model. Mutat Res 722: 114-118, 2011.

55. Maes OC, An J, Sarojini H, Wu HL and Wang E: Changes in microRNA expression patterns in human fibroblasts after low-LET radiation. J Cell Biochem 105: 824-834, 2008.

56. Niemoeller OM, Niyazi M, Corradini S, Zehentmayr F, Li M, Lauber K and Belka C: MicroRNA expression profiles in human cancer cells after ionizing radiation. Radiat Oncol 6: 29, 2011.

57. Zhang X, Ng WL, Wang P, Tian L, Werner E, Wang H, Doetsch P and Wang Y: MicroRNA-21 modulates the levels of reactive oxygen species by targeting SOD3 and TNFa. Cancer Res 72: 4707-4713, 2012

58. Fan PC, Zhang Y, Wang Y, Wei W, Zhou YX, Xie Y, Wang X, Qi YZ, Chang L, Jia ZP, et al: Quantitative proteomics reveals mitochondrial respiratory chain as a dominant target for carbon ion radiation: Delayed reactive oxygen species generation caused DNA damage. Free Radic Biol Med 130: 436-445, 2019.

59. Zulato E, Ciccarese F, Agnusdei V, Pinazza M, Nardo G, Iorio E, Curtarello M, Silic-Benussi M, Rossi E, Venturoli C, et al: LKB1 loss is associated with glutathione deficiency under oxidative stress and sensitivity of cancer cells to cytotoxic drugs and $\gamma$-irradiation. Biochem Pharmacol 156: 479-490, 2018.

60. Urbanelli L, Magini A, Buratta S, Brozzi A, Sagini K and Polchi A: Signaling pathways in exosomes biogenesis, secretion and fate. Genes 4: 152-170, 2013.
61. Cardiello C, Cavallini L, Spinelli C, Yang J, Reis-Sobreiro M, de Candia P, Minciacchi VR and Di VD: Focus on extracellular vesicles: New frontiers of cell-to-cell communication in cancer. Int J Mol Sci 17: 175, 2016.

62. Liu LS, Sun P, Li Y, Liu SS and Lu Y: Exosomes as critical mediators of cell-to-cell communication in cancer pathogenesis and their potential clinical application. Transl Cancer Res 8: 298-311, 2019.

63. Mutschelknaus L, Peters C, Winkler K, Yentrapalli R, Heider T, Atkinson MJ and Moertl S: Exosomes derived from squamous head and neck cancer promote cell survival after ionizing radiation. PLoS One 11: e0152213, 2016.

64. Arscott WT, Tandle AT, Zhao S, Shabason JE, Gordon IK, Schlaff CD, Zhang G, Tofilon PJ and Camphausen KA: Ionizing radiation and glioblastoma exosomes: Implications in tumor biology and cell migration. Transl Oncol 6: 638-648, 2013.

65. Hazawa M, Tomiyama K, Saotome-Nakamura A, Obara C, Yasuda T, Gotoh T, Tanaka I, Yakumaru H, Ishihara H and Tajima K: Radiation increases the cellular uptake of exosomes through CD29/CD81 complex formation. Biochem Biophys Res Commun 446: 1165-1171, 2014.

66. O'Brien K, Rani S, Corcoran C, Wallace R, Hughes L, Friel AM, McDonnell S, Crown J, Radomski MW and O'Driscoll L: Exosomes from triple-negative breast cancer cells can transfer phenotypic traits representing their cells of origin to secondary cells. Eur J Cancer 49: 1845-1859, 2013.

67. Costa-Silva B, Aiello NM, Ocean AJ, Singh S, Zhang H, Thakur BK, Becker A, Hoshino A, Mark MT, Molina H, et al: Pancreatic cancer exosomes initiate pre-metastatic niche formation in the liver. Nat Cell Biol 17: 816-826, 2015.

This work is licensed under a Creative Commons Attribution-NonCommercial-NoDerivatives 4.0 International (CC BY-NC-ND 4.0) License. 